This is the author's final, peer-reviewed manuscript as accepted for publication. The publisher-formatted version may be available through the publisher's web site or your institution's library.

\title{
Production process for stem cell based therapeutic implants: expansion of the production cell line and cultivation of encapsulated cells
}

C. Weber, S. Pohl, R. Poertner, Pablo Pino-Grace, D. Freimark,

C. Wallrapp, P. Geigle, and P. Czermak

\section{How to cite this manuscript (APA format)}

If you make reference to this version of the manuscript, use the following citation format:

Weber, C., Pohl, S., Poertner, R., Pino-Grace, P., Freimark, D., Wallrapp, C., Geigle, P., Czermak, P. (2010). Production process for stem cell based therapeutic implants: expansion of the production cell line and cultivation of encapsulated cells. Retrieved from http://krex.ksu.edu

\section{Published Version Information}

Weber, C., Pohl, S., Poertner, R., Pino-Grace, P., Freimark, D., Wallrapp, C., Geigle, P., Czermak, P. (2010). Production process for stem cell based therapeutic implants: expansion of the production cell line and cultivation of encapsulated cells. Advances in Biochemical Engineering Biotechnology, 123, 143-162.

Copyright: ( ) Springer, Part of Springer Science+Business Media

Digital Object Identifier (DOI): 10.1007/10_2009_25

Publisher's Link: http://springerlink.com/content/bkl7g367405vq785/fulltext.html

This item was retrieved from the K-State Research Exchange (K-REx), the institutional repository of Kansas State University. K-REx is available at http://krex.ksu.edu 


\title{
Production process for stem cell-based therapeutic implants - Expansion of the production cell line and cultivation of encapsulated cells
}

\author{
C. Weber ${ }^{1}$, S. Pohl' ${ }^{1}$ R. Poertner ${ }^{2}$, Pablo Pino-Grace ${ }^{1}$, D. Freimark ${ }^{1}$, C. \\ Wallrapp $^{3}$, P. Geigle ${ }^{3}$, and P. Czermak ${ }^{1,4}$ \\ ${ }^{1}$ Institute of Biopharmaceutical Technology, University of Applied Sciences Giessen- \\ Friedberg, Giessen-Germany \\ ${ }^{2}$ Institute of Bioprocess and Biosystem Technology, University of Hamburg-Harburg, \\ Hamburg, Germany \\ ${ }^{3}$ CellMed AG, Alzenau, Germany \\ ${ }^{4}$ Department of Chemical Engineering, Kansas State University, Manhattan KS-USA
}

\section{Introduction}

Cell based therapy can be defined as the implantation of autologous, allogenic or xenogenic cells for the replacement of damaged cells or organ functions. Either the implanted cells are able to assume this function by themself or they stimulate other cells, which then can cause a regeneration of the tissue or organ function. Examples are the treatment of diabetes mellitus with insulin- and GLP-1- secreting cells or Parkinson disease with dopamine-secreting cells as well as the implantation of mesenchymal stem cells for regeneration of heart, cartilage or bone tissue [1-6].

The implantation of allogenic (or xenogenic) cells demands a protection against host-versus-graft reactions which can be achieved by a suppression of the recipient's immune system or by an encapsulation of the transplanted scells.

Promising, for the treatment of many endocrine or degenerative diseases are microencapsulated stem cells, for example the CellBead ${ }^{\circledR}$ system developed by the CellMed AG (Alzenau, Germany). These cell beads consist of an inner cell containing core which is surrounded by an alginate capsule (Figure 1). Each cell bead contains about 2000 to 3000 cells in a non-proliferating state. The diameter of the cell containing core bead is about $400 \mu \mathrm{m}$ and the diameter of the alginate capsule between 500 and $600 \mu \mathrm{m}$. 


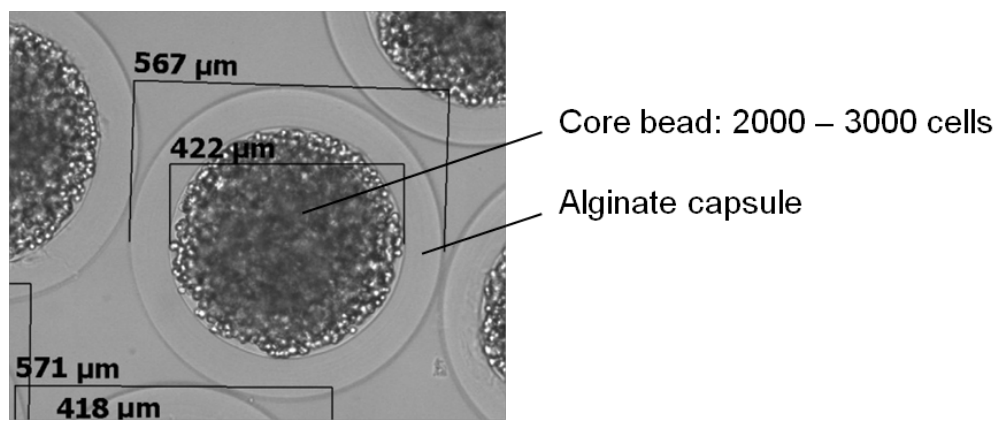

Figure 1: Light-microscopic image of cell beads.

The allogenic production cell line is based on human mesenchymal stem cells, which are transfected with the gene of the catalytic subunit of human telomerase. The telomerase activity counteracts the shortening of the telomeres after each cell cycle, that means a transformation of the cells to a permanent cell line [7]. Dependent on the designated use the cells are genetically modified with additional therapeutic genes.

The cell beads can be implanted by injection using a sterile syringe. At the implantation place the cells are provided with nutrients by diffusion through the capsule and in turn release therapeutic molecules. Antigens and components of the host immune system cannot penetrate through the capsule (Figure 2). The advantages of this therapeutical system are a continuous drug delivery and due to the local application high drug concentrations at the point of implantation. Furthermore, a production in stock is possible since a cell line is used.

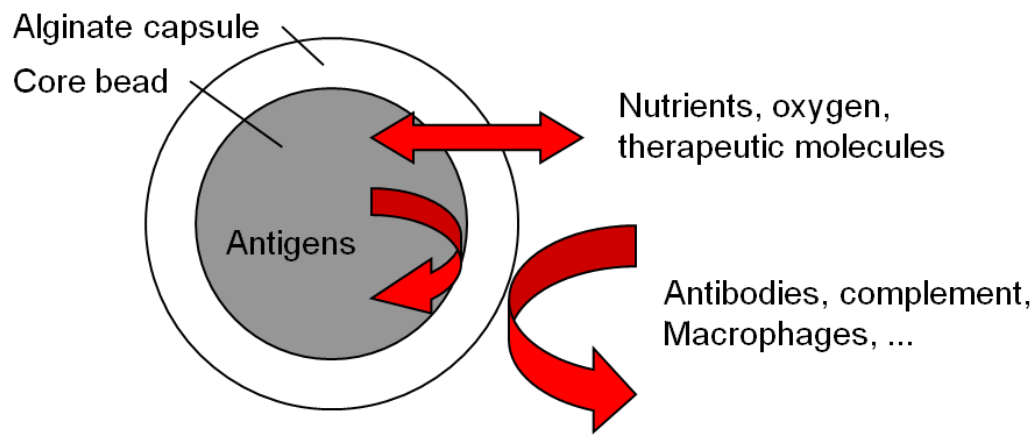

Figure 2: The alginate capsule of a cell bead acts as a semipermeable membrane.

The implantion of this cell therapeutic system behind the blood-brain barrier makes them suitable for the treatment of e.g. stroke. Clinical phase 1 studies with 
GLP-1-transfected cells revealed a reduced loss of neuronal cells in a controlled cortical impact rat model due to the implantation of GLP-1 secreting cell beads [8]. Originally, intestinal cells secret GLP-1in reply to food intake. GLP-1 enhances insulin secretion of beta-cells as well as promoting insulin sensitivity. Since GLP-1 receptors are also expressed throughout the mammalian brain, the implantation of GLP-1 secreting cell beads into the brain may cause neurotrophic and neuroprotective effects.

The production process of cell based implants consists of three steps, whereas this article is focused on the first and third production steps (Figure 3).

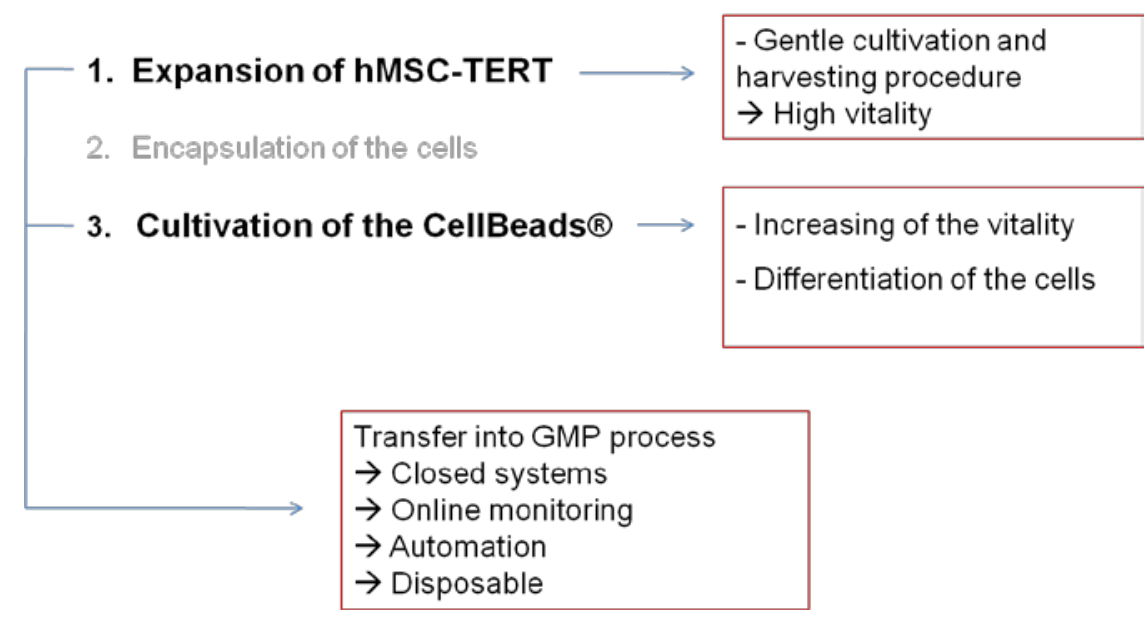

Figure 3: Steps and requirements of the cell bead production process.

Due to the fact that the cells themselves are the product, the requirements of the stem cell expansion process differ from a common mammalian cell culture, where, for example, a virus or protein is the product.

The cultivation and harvesting procedure for the expansion of the stem cell based production cell line should be very gentle in order to obtain high yields and vitalities of harvested cells. The used carrier should be non-porous which ease the separation of detached cells from the carrier.

The cell bead cultivation process aims to increase the vitality of the encapsulated cells. A decrease of the cell vitality of the implants may be caused by the harvesting and encapsulation procedure. Apoptotic cells shall be decomposed during this cultivation.

An optional differentiation of the cell beads may support the cell survival at the transplantation place. Furthermore, a differentiation may induce the expression of therapeutic molecules. 
Here we introduce two fixed-bed bioreactor systems, one for the expansion of the adherent production cell line and the other for the cultivation of the cell beads. As an example the application of an adipogenic differentiation protocol was investigated.

Both fixed-bed systems have to be transferred into a GMP-process. Therefore some requirements are addressed to the reactor systems. For maintaining sterility during the process they have to be designed as a closed system with the possibility of online monitoring. Furthermore, an automation of the process should be enabled to reduce human error and labor input. A simple design of the reactor system and its peripheral components benefit the manufacturing of disposables, which reduces extensive cleaning procedures and documentation effort. Figure 3 gives an overview about the cell bead production process and its requirements.

\section{Expansion of hMSC-TERT}

\section{Reactor system}

Many disposable reactor systems used in the cultivation of adherent animal cells like T-flasks, roller bottles, wave reactors, stirred-tank reactors or spinner flasks are established, but they show more or less drawbacks. T-flasks and their cognate systems are labor consuming in operation, or intricate in automation. Suspension reactors in combination with microcarrier have the drawback that a special system for the separation of the enzymatically detached cells from the carrier is necessary. This counteracts a simple design which is demanded for manufacturing as a disposable. Therefore a fixed-bed bioreactor system was developed, which is based on non-porous carrier. The advantage of non-porous carrier is that the adherent cells, located on the carrier surface, can be easily flushed out of the reactor with the medium flow after enzymatic detachment. A carrier screening has revealed that non-porous borosilicate glass spheres (BSGS) are most suitable in respect to the growth behavior, cell harvest and nutrient supply.

Figure 4 shows a prototype of the fixed-bed reactor. It consists of a glass cylinder with a stainless steel lid and bottom plate, which are equipped with hose connectors for the medium inlet and outlet. A funnel shaped insert leads to a nearly uniform inflow. The periphery of the fixed bed consists of some flasks that act as conditioning, collecting, waste and storage vessel, the tubing, some pinch valves, two peristaltic pumps, single use noninvasive oxygen sensors (PreSens Precision Sensing GmbH, Regensburg, Germany) for process monitoring and sterile air filter for pressure adjusting of the vessels. All parts except the valves and the pumps can be designed for production as a disposable, or they are already available as commercial single use items. A further advantage of this system is a 
comfortable automation of the process including the inoculation, culturing and harvesting procedure.

The oxygen supply can be provided by a surface aeration or in larger systems with a single use membrane oxygenator. Bubble aeration would have the drawbacks of foam forming when serum containing medium is used.

The reactor system can be operated in a humidified incubator at $37^{\circ} \mathrm{C}$ and $5 \%$ $\mathrm{CO}_{2}$. Larger scales demand special heating strategies for the fixed bed and the conditioning vessel. Furthermore, a gas mix station is demanded when the medium is aerated by using membrane oxygenators in order to enrich the feed air with $\mathrm{CO}_{2}$, which is necessary for a $\mathrm{pH}$ adjustment of sodium bicarbonate buffered medium.

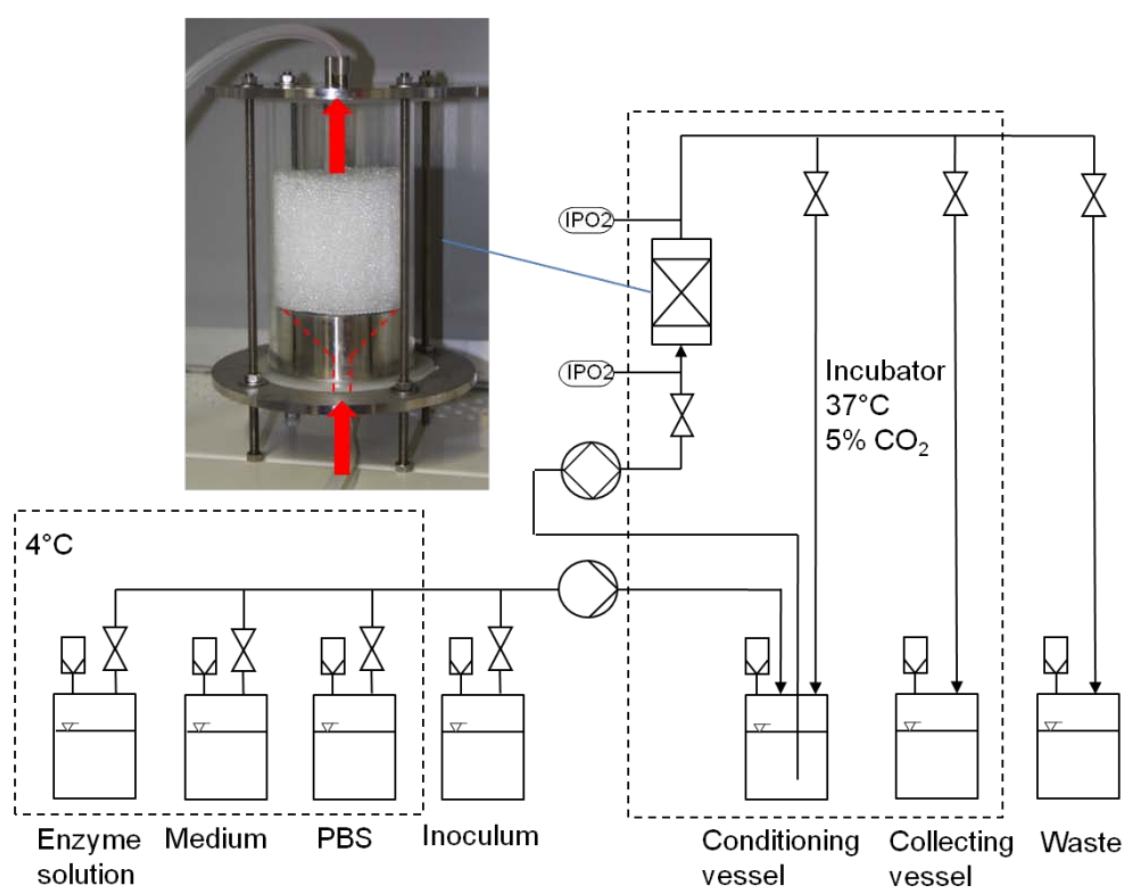

Figure 4: Fixed-bed reactor system for the expansion of hMSC-TERT.

For determination of growth and consumption kinetics and for scale up calculations a mathematical model was used that is shown here in a simplified manner (Figure 5). 


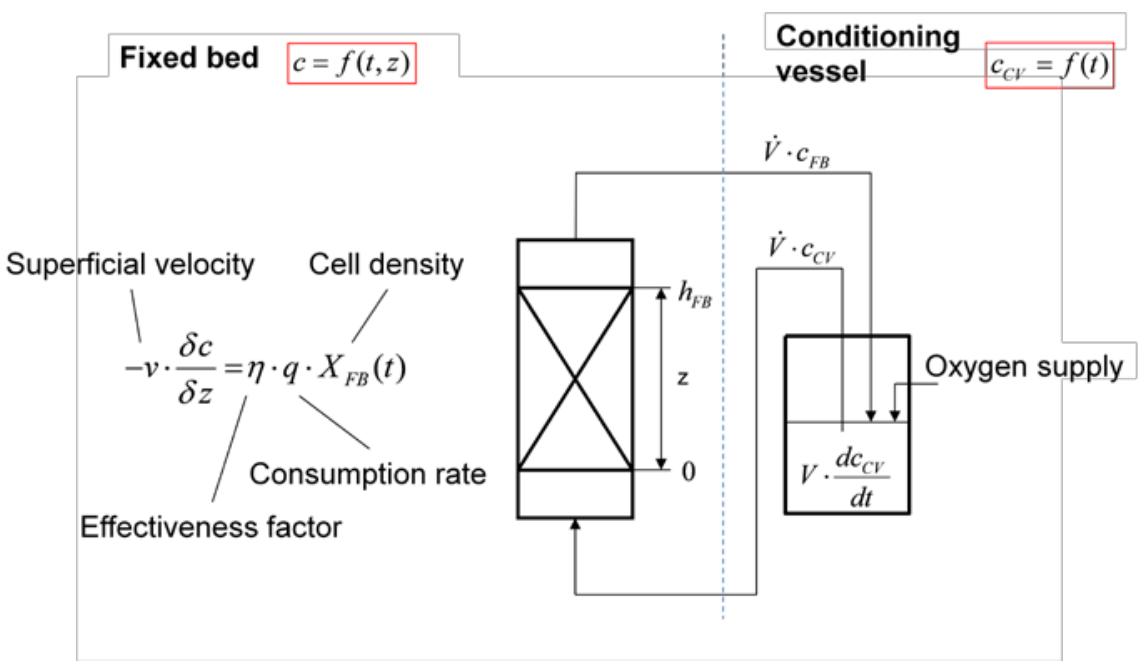

Figure 5: Simplified illustration of the mass balances of the fixed-bed reactor and its associated conditioning vessel.

The system is mainly composed of the interacting compartments, the fixed bed and the conditioning vessel. The concentration $c$ of any nutrient component in the fixed bed depends on time and axial position $z$ and can be expressed by this convection- consumption equation:

$-v \cdot \frac{\delta c}{\delta z}=\eta \cdot q \cdot X_{F B}(t)$

\section{Equation 1}

with the superficial velocity $v$, which is defined as the flow velocity in the reactor tube without the packed bed, the cell specific consumption rate $q$ of the regarded nutrient component, the time dependent and volume specific cell density

$X_{F B}(t)=X_{F B}^{0} \cdot e^{\mu \cdot t}$

Equation 2

and the effectiveness factor $\eta$, that considers mass transfer resistance [9-14]. The growth rate $\mu$ and the glucose consumption rate $q_{G l c}$ can be described by Monod kinetics:

$\mu=\mu_{\max } \cdot \frac{c_{G l c}}{c_{G l c}+k_{M, \mu}}$

Equation 3 
$q_{G l c}=q_{G l c, \max } \cdot \frac{c_{G l c}}{c_{G l c}+k_{M, q_{G l c}}}$

Equation 4

with the Monod constants $k_{M, q_{G l c}}$ and $k_{M, \mu}$ whereas the oxygen consumption rate $q_{O x}$ is assumed to be concentration independent:

$q_{O x}=$ const.

Equation 5

For the concentration $c_{C V}$ in the conditioning vessel only time dependence is assumed. It can be described by balancing the nutrient in- and outflow:

$V \cdot \frac{\delta c_{C V}}{\delta t}=-\dot{V} \cdot c_{C V}+\dot{V} \cdot c_{F B}$ Equation 6

with the concentration at the reactor outlet $c_{F B}$, the medium volume $V$ and the volume flow $\dot{V}$. In the case of an oxygen balance equation 6 has to be extended by the oxygen transfer rate OTR:

$V \cdot \frac{\delta c_{C V, O x}}{\delta t}=-\dot{V} \cdot c_{C V, O x}+\dot{V} \cdot c_{F B, O x}+O T R$

Equation 7

\section{Expansion of hMSC-TERT in lab scale}

Fixed-bed cultivations of hMSC-TERT were performed in scales up to a bed volume of $300 \mathrm{~cm}^{3}$. With these cultivations several process relevant problems could be investigated (Figure 6).

A carrier screening was performed to find a suitable carrier regarding growth and harvesting behavior of the hMSC-TERT.

Inoculation and harvesting procedures were developed, which are automatable and leading to high yields of adhered or detached cells, respectively. Furthermore, the harvesting procedure has to result in a high vitality of the detached cells.

The lab scale bioreactor system for the cell expansion has to be scaled up to the production scale. Therefore a maximal superficial velocity has to be defined, 
in order to avoid negative effects on the cell growth caused by shear stress. Model parameters like growth and consumption rates, which are necessary for scale up calculations, were determined by fitting them to the experimental data.

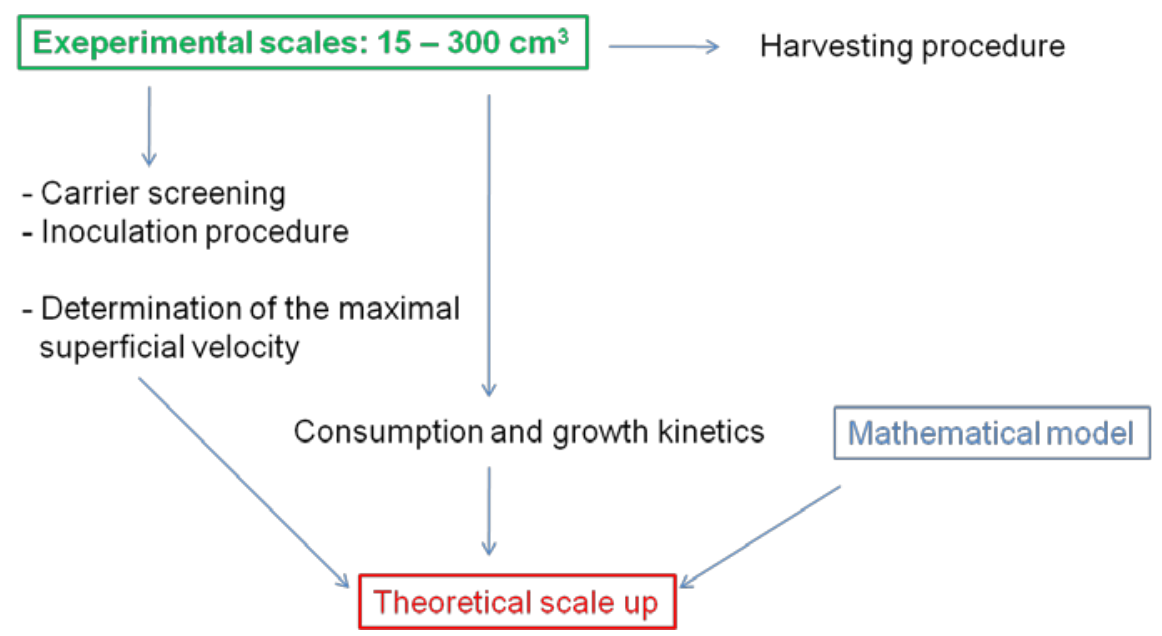

Figure 6: Overview of performed lab scale experiments for the development of a fixed bed based expansion process for hMSC-TERT.

\section{Carrier screening}

Non-porous borosilicate glass spheres of 1, 2 and $3 \mathrm{~mm}$ diameter as well as fibrous macroporous polyethylene terephthalate based carrier (BioNoc $\mathrm{II}^{\mathrm{TM}}$, Cesco Bioengineering Co, Taichung, Taiwan) were investigated and compared.

Therefore, reactors were filled with $60 \mathrm{~cm}^{3}$ carrier and inoculated with a cell number corresponding to 5000 cells per $\mathrm{cm}^{2}$. During the four hour inoculation procedure without perfusion of the fixed bed, the reactors were manually turned around $180^{\circ}$ after $10,40,130$ and 240 min in order to return sedimented and nonattached cells into the fixed bed. After the inoculation procedure, the cultivation was started by perfusion of the system with EMEM (Eagle's Minimal Essential Medium) supplemented with $10 \%$ fetal calf serum (FCS). Table 1 gives more detail to the cultivations. The final cell numbers at the end of the cultivations were determined by counting of crystal violet stained nuclei after lysis of the cells with citric acid [15]. 
Table 1: Cultivations of hMSC-TERT in $60 \mathrm{~cm}^{3}$ fixed-bed reactors aimed at finding suitable carrier.

\begin{tabular}{lllll}
\hline Carrier & $\begin{array}{l}\text { Sphere } \\
\text { diameter } \mathrm{d}_{\mathrm{S}} \\
{[\mathrm{mm}]}\end{array}$ & $\begin{array}{l}\text { Growth surface per } \\
60 \mathrm{~cm}^{3} \text { fixed bed A } \\
{\left[\mathrm{cm}^{2}\right]}\end{array}$ & $\begin{array}{l}\text { Medium } \\
\text { volume V } \\
{[\mathrm{ml}]}\end{array}$ & $\begin{array}{l}\text { Superficial } \\
\text { Velocity v } \\
{[\mathrm{m} / \mathrm{s}]}\end{array}$ \\
\hline \hline BioNoc II ${ }^{\mathrm{TM}}$ & - & 9600 & 1000 & $1.5 \times 10^{-4}$ \\
\hline \multirow{2}{*}{ Borosilicate } & 1 & 2196 & 500 & $3.0 \times 10^{-4}$ \\
glass spheres & 2 & 1098 & 500 & $3.0 \times 10^{-4}$ \\
& 3 & 732 & 500 & $3.0 \times 10^{-4}$ \\
\hline
\end{tabular}

The results of the cultivations (Figure 7) are summarized in Table 2. The highest growth rate as well as the highest cell density after 160 hours was reached with $2 \mathrm{~mm}$ borosilicate glass spheres. The lowest number of attached cells after the inoculation procedure was obtained with BioNoc $\mathrm{II}^{\mathrm{TM}}$. Channeling was detected by using of borosilicate glass spheres with a diameter of $1 \mathrm{~mm}$, which means a nonoptimal nutrient supply and thus limitations of the cells. 


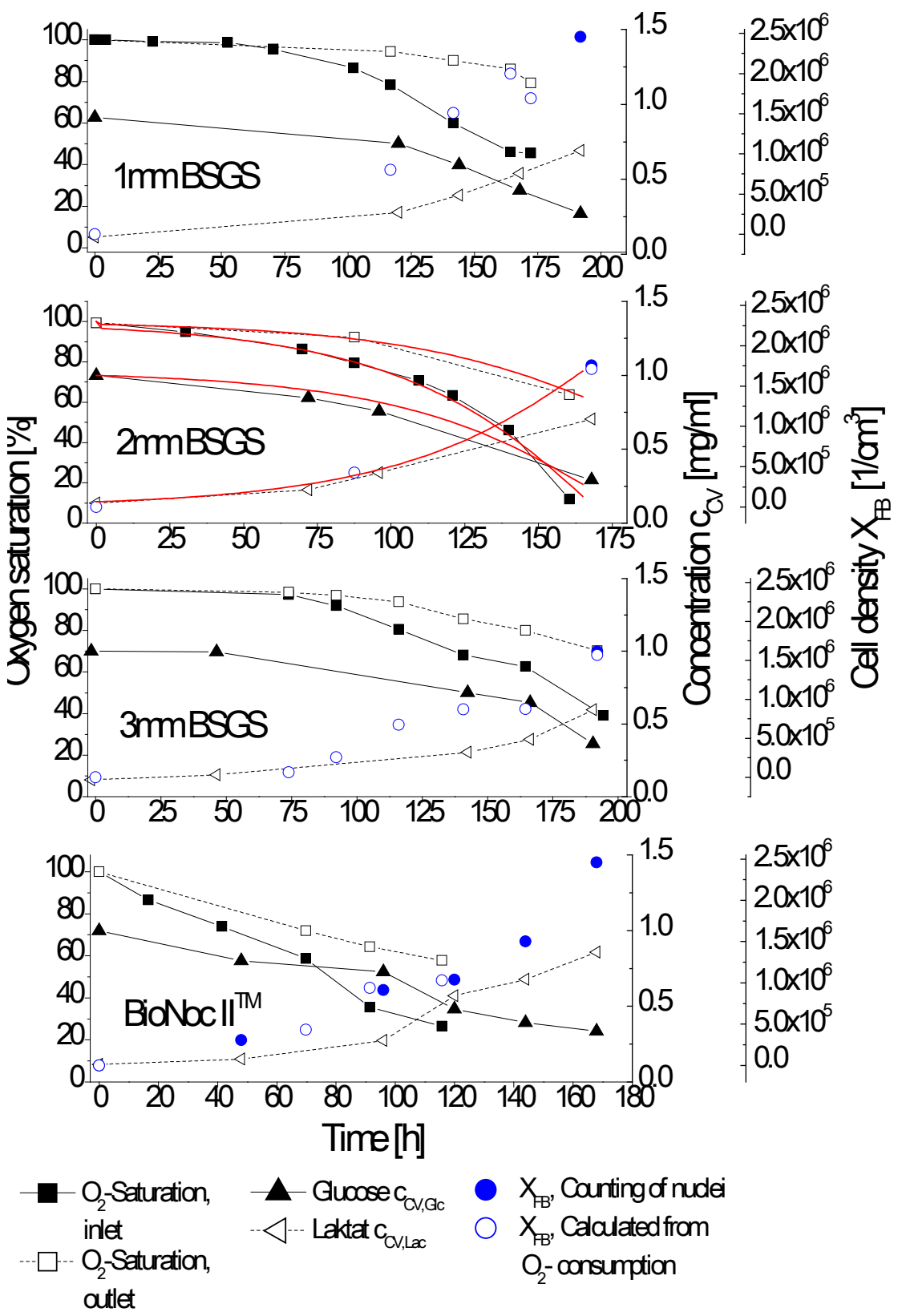

Figure 7: Cultivations of hMSC-TERT in $60 \mathrm{~cm}^{3}$ fixed-bed reactors on nonporous borosilicate glass spheres (BSGS) and macroporous BioNoc II $^{\mathrm{TM}}$ carrier. Red curves (2 mm BSGS) were simulated using the model. BSGS: Borosilicate glass spheres 
Table 2: Results of the comparative cultivations of hMSC-TERT in $60 \mathrm{~cm}^{3}$ fixed-bed reactors on different carrier. The mean growth rates $\mu_{\max }$ and the cell densities $X_{F B}$ after the inoculation procedures were obtained by fitting of Equation 2 to the experimental data. BSGS: Borosilicate glass spheres

\begin{tabular}{llllll}
\hline & Units & $1 \mathrm{~mm}$ BSGS & $2 \mathrm{~mm}$ BSGS & $3 \mathrm{~mm}$ BSGS & BioNoc II $^{\mathrm{TM}}$ \\
\hline \hline Cultivation time & {$[\mathrm{h}]$} & 192 & 168 & 192 & 168 \\
\hline Mean growth rate $\mu_{\max }$ & {$[1 / \mathrm{d}]$} & $0.307 \pm 0.062$ & $0.487 \pm 0.042$ & $0.372 \pm 0.063$ & $0.391 \pm 0.034$ \\
\hline Cell density at the end of & {$\left[1 / \mathrm{cm}^{2}\right]$} & $6.69 \times 10^{4}$ & $9.64 \times 10^{4}$ & $1.32 \times 10^{5}$ & $1.54 \times 10^{4}$ \\
cultivation $X_{F B}$ & {$\left[1 / \mathrm{cm}^{3}\right]$} & $2.45 \times 10^{6}$ & $1.75 \times 10^{6}$ & $1.61 \times 10^{6}$ & $5.63 \times 10^{5}$ \\
\hline Cell density after $160 \mathrm{~h}$ & {$\left[1 / \mathrm{cm}^{2}\right]$} & $(5.11 \pm 2.20) \times 10^{4}$ & $(9.32 \pm 2.55) \times 10^{4}$ & $(7.92 \pm 3.60) \times 10^{4}$ & $(1.31 \pm 0.29) \times 10^{4}$ \\
$X_{F B}$ & {$\left[1 / \mathrm{cm}^{3}\right]$} & $(1.66 \pm 0.72) \times 10^{5}$ & $(1.71 \pm 0.47) \times 10^{5}$ & $(9.50 \pm 4.31) \times 10^{5}$ & $(2.01 \pm 0.46) \times 10^{5}$ \\
\hline Cell density after the in- & {$\left[1 / \mathrm{cm}^{2}\right]$} & $(6.58 \pm 2.84) \times 10^{3}$ & $(3.68 \pm 0.99) \times 10^{3}$ & $(6.63 \pm 3.01) \times 10^{3}$ & $(9.68 \pm 2.10) \times 10^{2}$ \\
oculation procedure $X_{F B}^{0}$ & {$\left[1 / \mathrm{cm}^{3}\right]$} & $(2.14 \pm 0.92) \times 10^{5}$ & $(6.63 \pm 1.81) \times 10^{4}$ & $(7.96 \pm 3.61) \times 10^{4}$ & $(1.55 \pm 0.34) \times 10^{5}$ \\
\hline $\mathrm{R}^{2}$ & {$[-]$} & 0.946 & 0.998 & 0.932 & 0.986 \\
\hline$*$ channeling & & & & &
\end{tabular}

* channeling 
Beside the growth behavior the yield after a harvesting procedure was used for an evaluation of the carrier. Therefore fixed beds consisted of $2 \mathrm{~mm}$ glass spheres or BioNoc $\mathrm{II}^{\mathrm{TM}}$ were cyclic perfused with Accutase ${ }^{\mathrm{TM}}$ or Trypsin solution, respectively, for 20 minutes at a superficial velocity of $1.3 \times 10^{-4} \mathrm{~m} / \mathrm{s}$.

Accutase $^{\mathrm{TM}}$ was more effective regarding the yield of detached cells than Trypsin (Figure 8). The highest yield of $92 \%$ was obtained with $2 \mathrm{~mm}$ glass spheres and Accutase ${ }^{\mathrm{TM}}$.

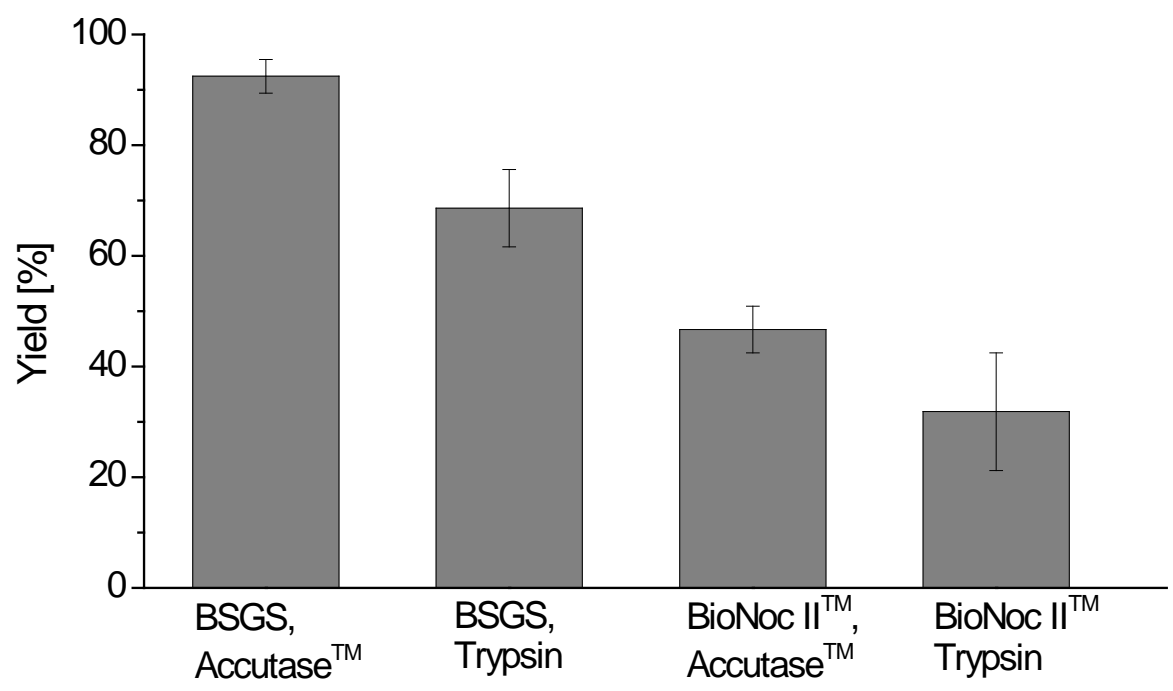

Figure 8: Preliminary harvesting experiments in fixed-bed reactors containing $2 \mathrm{~mm}$ borosilicate glass spherese or BioNoc $\mathrm{II}^{\mathrm{TM}}$, respectively. The beds were cyclic perfused with enzyme solution for 20 minutes. The data represent the mean \pm standard deviation of four experiments.

Considering the previous facts, borosilicate glass spheres with a diameter of $2 \mathrm{~mm}$ are most suitable for the cultivation and harvesting procedure of hMSCTERT. The next steps including the development of automatable inoculation and harvesting procedures as well as the determination of kinetic parameters for scale up calculations were performed with $2 \mathrm{~mm}$ borosilicate glass spheres.

\section{Inoculation procedure}

The main problem by inoculation of the fixed bed was that non-adherend cells sedimented and did not get the chance to adhere to the carrier when the system is 
filled with cell suspension and incubated without perfusion. This yielded in a small amount of adhered cells and an axial cell density profile. Therefore, perfusion steps should be included in the inoculation procedure.

Figure 9 shows an inoculation procedure with intermittent perfusion intervals. The yield, which is defined as the ratio of adherend cells to the inoculated cell number could be increased from $30 \%$, without perfusion, to about $50 \%$, with perfusion.
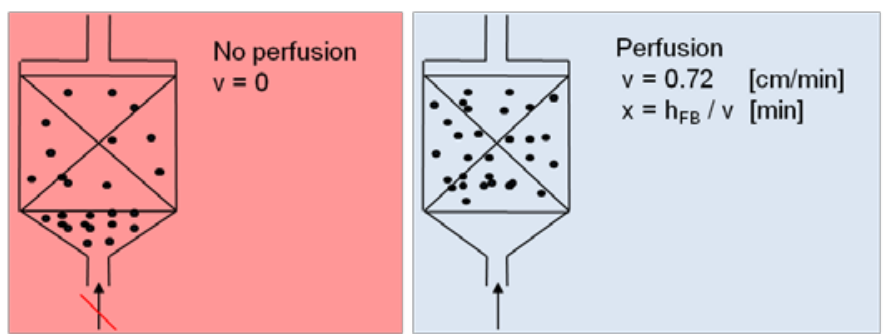

\begin{tabular}{|l|l|l|l|l|l|l|l|l}
$30 \min$ & $x \min$ & $30 \min$ & $x \min$ & $30 \min$ & $x \min$ & $30 \min$ & $x \min$ & cultivation
\end{tabular}

Figure 9: Scheme of the inoculation procedure. Repeated perfusion steps enhance the number of attached cells and thus the yield of the inoculation procedure.

\section{Determination of the maximal superficial velocity}

Due to the non-porosity of the glass carrier, the cells are totally exposed to the shear stress caused by the medium flow, which requires a definition of a maximal superficial velocity. For this purpose, hMSC-TERT were cultured in $25 \mathrm{~cm}^{3}$ fixed beds at different superficial velocities. The growth rate was used as an evaluation parameter. A reference culture in 6-well cell culture plates was performed to get the maximal growth rate at $\mathrm{v}=0$.

The growth rate starts to decrease at about $3.0 \times 10^{-4} \mathrm{~m} / \mathrm{s}$ (Figure 10). This velocity was used for scale up calculations and experimental determinations of growth and consumption kinetics in fixed-bed reactors. 


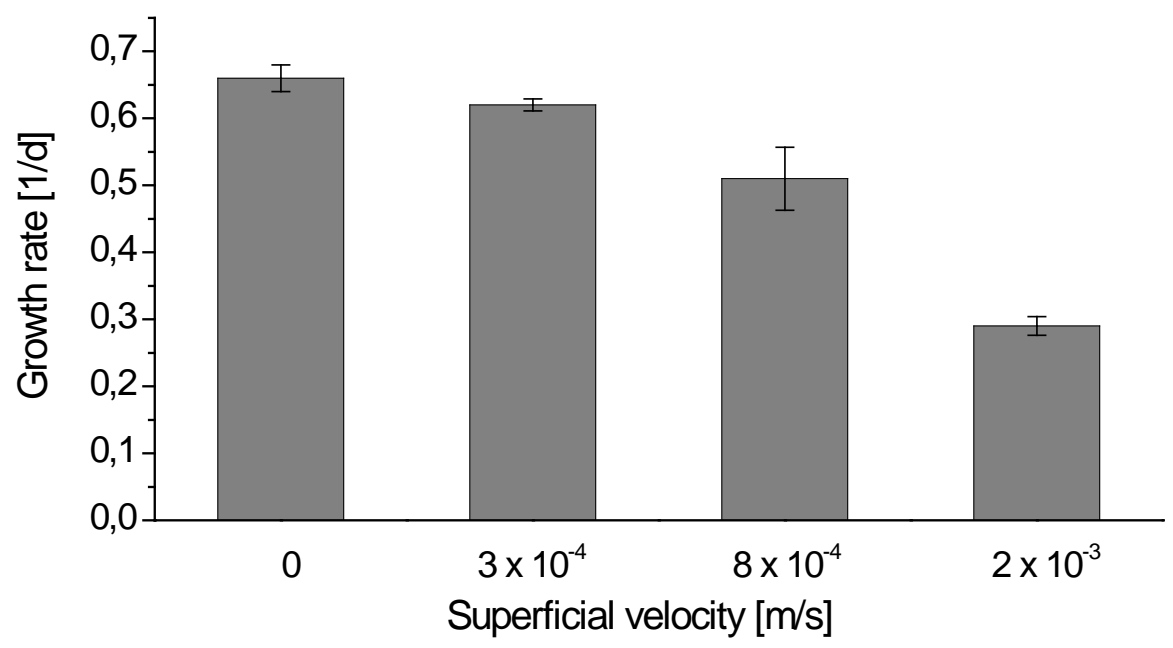

Figure 10: Growth rates of hMSC-TERT in a fixed bed consisting of non-porous borosilicate glass spheres with a diameter of $2 \mathrm{~mm}$ at different superficial velocities. The data represent the mean \pm standard deviation of four cultivations.

\section{Cultivation in different scales - consumption and growth kinetics}

Cultivations were performed in scales from 15 to $300 \mathrm{~cm}^{3}$. Growth, oxygen and glucose consumption kinetics were determined by fitting of the model parameters to the experimental data. Glutamine wasn't considered since it is an unimportant energy source for hMSC [16]. The modeled curves for a $60 \mathrm{~cm}^{3}$ scale are exemplarily shown in Figure 7.

Table 3 shows the fitted model parameters. The growth and consumption rates are comparable to those reported in the literature. Glucose consumption and growth rates of human mesenchymal stem cells are referred to be $(0.23-1.22) \mathrm{x}$ $10^{-7} \mathrm{mg} / \mathrm{h} /$ cell $[17,18]$ and $0.33-0.941 / \mathrm{d}$ [15, 16, 19-22], respectively. Oxygen consumption rates of $(1.22-3.20) \times 10^{-8} \mathrm{mg} / \mathrm{h} /$ cell are reported for various human cell types [23-27].

Most important for scale up considerations is the oxygen consumption rate. 
Table 3: Consumption and growth kinetics of hMSC-TERT cultured on $2 \mathrm{~mm}$ borosilicate glass spheres in fixed-bed reactors at 15,60 and $300 \mathrm{~cm}^{3}$ scales. The data were obtained by fitting the model parameters to the experimental data.

\begin{tabular}{lll}
\hline Maximal growth rate $\mu_{\max }$ & $0.55-0.69$ & {$[1 / \mathrm{d}]$} \\
Monod constant $k_{M, \mu}$ & $0.135-0.160$ & {$[\mathrm{mg} / \mathrm{ml}]$} \\
Maximal glucose consumption rate $q_{G l c, \max }$ & $(8.0-11.8) \times 10^{-8}$ & {$[\mathrm{mg} / \mathrm{h} / \mathrm{cell}]$} \\
Monod constant $k_{M, q_{G l c}}$ & $0.10-0.16$ & {$[\mathrm{mg} / \mathrm{ml}]$} \\
Oxygen consumption rate $q_{O x}$ & $(0.98-2.14) \times 10^{-8}$ & {$[\mathrm{mg} / \mathrm{h} / \mathrm{cell}]$} \\
\hline
\end{tabular}

\section{Harvesting procedure}

A drawback of the used preliminary harvesting procedure for the carrier screening was that, due to the cyclic perfusion of the enzyme solution, already detached cell were repeatedly passed through the reactor system. This caused shear stress which led to a decrease in vitality to values below 90\% (data not shown). Therefore, a harvesting procedure was developed at which the cell suspension will be directly to the collecting vessel (Figure 11).

In the first step, cells become detached by perfusion of the fixed bed for 10 minutes with Accutase ${ }^{\mathrm{TM}}$ solution at a superficial velocity of $1.8 \times 10^{-4} \mathrm{~m} / \mathrm{s}$. After this the cells get flushed out by perfusion with medium at a superficial velocity of $3.2 \times 10^{-3} \mathrm{~m} / \mathrm{s}$ for 2 minutes. This harvesting procedure resulted in a yield of detached and separated cells of approximately $82 \%$ and a vitality of about $96 \%$.

The advantages of this procedure are the comfortable automation and separation of the detached cells without any further system components or process steps.

1. Perfusion with Accutase $\mathrm{TM}^{\mathrm{TM}}$

$10 \mathrm{~min}$

$v=1.8 \times 10^{-4}[\mathrm{~m} / \mathrm{s}]$

2. Perfusion with medium

$$
\begin{aligned}
& 2 \min \\
& v=3.2 \times 10^{-3}[\mathrm{~m} / \mathrm{s}]
\end{aligned}
$$

\section{Cell detachment}

Separation of the cells from the carrier

Figure 11: Harvesting of hMSC-TERT in fixed-bed reactors based on non-porous borosilicate glass spheres. 


\section{Theoretical scale up of the hMSC-TERT expansion process}

For scale up calculations of the fixed bed, mainly the dissolved oxygen concentration has to be considered, since it is magnitudes lower than other limiting medium components such as glucose. The oxygen concentration or saturation, respectively, decreases in axial direction that demands a definition of a maximal fixed-bed height $h_{F B}$ (Figure 12).
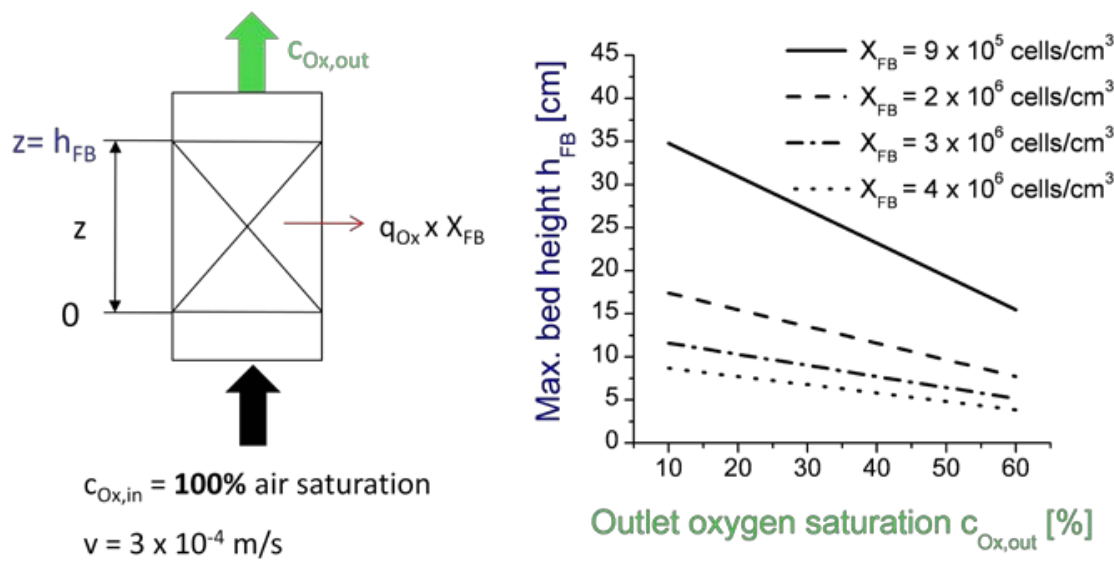

Figure 12: Dependency of the bed height on the outlet oxygen saturation and target cell density calculated using the model of the cultivation process and the maximal oxygen consumption rate (Table 3 ).

The maximal fixed-bed height depends, assuming an 100\% air saturated inflow concentration and a constant inflow velocity $\left(3.0 \times 10^{-4} \mathrm{~m} / \mathrm{s}\right)$, on the maximal cell density and the minimal oxygen concentration in the fixed bed, which can be found at the outflow region. This maximal bed height can be calculated by using the previously described model:

$h_{F B}=f\left(X_{F B}, c_{O x, \text { out }}\right)$

Equation 8

Using the maximal bed height, a calculation of the maximal volume $V_{F B}$ of a single fixed bed as a function of the thickness ratio $T R$ and with it a calculation of the needed number $n_{F B}$ of parallel operated fixed-bed reactors for the cultivation of a certain target cell number $N_{X}$ is possible: 
$V_{F B}=h_{F B} \cdot \pi \cdot\left(\frac{h_{F B}}{T R \cdot 2}\right)^{2}$

$n_{F B}=\frac{N_{X}}{X_{F B} \cdot V_{F B}}$
Equation 9

Equation 10

The reactor system was scaled exemplarily for the cultivation of a target cell number of 20 billion cells that is sufficient for approximately 200 single doses of cell beads with a volume of about $5 \mathrm{ml}$ per dose (Table 4).

The volume of a single fixed bed decreases with increasing cell number, thickness ratio, and outlet oxygen saturation. Small reactor volumes means a large number of parallel operated fixed-bed reactors, but this is very intricate and nonpractical regarding the handling and operation of the bioreactor system. Therefore a reduction of the target cell density, as well as a reduction of the thickness ratio and the outlet oxygen saturation is recommended. As a result of this small numbers of parallel operated reactors which can be handled and operated easier are obtained. The oxygen outlet concentration, of course, can only be decreased to an uncritical value.

Table 4: Numbers and volumes of parallel operated fixed beds needed for the cultivation of $2 \times 10^{10}$ cells as a function of thickness ratio, target cell density, and outlet oxygen saturation.

\begin{tabular}{|c|c|c|c|c|c|}
\hline & \multicolumn{2}{|c|}{ Thickness ratio $=1$} & \multicolumn{2}{|c|}{ Thickness ratio $=2$} & \\
\hline $\begin{array}{l}\text { Target cell den- } \\
\text { sity }\left[\mathrm{cm}^{-3}\right]\end{array}$ & $\begin{array}{l}\text { Fixed-bed } \\
\text { volume } \\
\mathrm{V}_{\mathrm{FB}}[\mathrm{L}] \\
\end{array}$ & $\begin{array}{l}\text { Number } \\
\text { of fixed } \\
\text { beds } n_{\mathrm{FB}}\end{array}$ & $\begin{array}{l}\text { Fixed-bed } \\
\text { volume } \\
\mathrm{V}_{\mathrm{FB}}[\mathrm{L}] \\
\end{array}$ & $\begin{array}{l}\text { Number } \\
\text { of fixed } \\
\text { beds } n_{\mathrm{FB}}\end{array}$ & $\begin{array}{l}\text { Total fixed- } \\
\text { bed volume } \\
{[\mathrm{L}]}\end{array}$ \\
\hline \multicolumn{6}{|c|}{ Outlet oxygen saturation: $\mathbf{2 0 \%}$} \\
\hline $1 \times 10^{6}$ & 20 & 1.1 & 5.2 & 4.2 & 21.9 \\
\hline $2 \times 10^{6}$ & 2.3 & 4.8 & 0.6 & 19.1 & 10.9 \\
\hline $4 \times 10^{6}$ & 0.3 & 18.3 & 0.07 & 73.1 & 5.5 \\
\hline \multicolumn{6}{|c|}{ Outlet oxygen saturation: $\mathbf{3 0 \%}$} \\
\hline $1 \times 10^{6}$ & 13.4 & 1.6 & 3.4 & 6.5 & 21.9 \\
\hline $2 \times 10^{6}$ & 1.5 & 7.3 & 0.4 & 29.0 & 10.9 \\
\hline $4 \times 10^{6}$ & 0.2 & 27.8 & 0.05 & 111.4 & 5.5 \\
\hline
\end{tabular}




\section{Cultivation of encapsulated cells}

\section{The reactor system}

The cell bead cultivation system is based on single use plastic syringes at which the cell beads which themself form the bed. The original piston is replaced by a custom made insert, which enables the perfusion of the fixed bed (Figure 13).

Beside the cultivation on a single dose level the advantages of this bioreactor system are a cryopreservation of the cell beads by direct freezing of the syringe and post-thaw an implantation of the cell beads using this syringe. This avoids contamination risky transfer steps. For this purpose, the insert can be designed in a manner that it can act as the original syringe piston.

The reactor periphery is similar to that of the hMSC-TERT expansion system. Furthermore the previously described mathematical model can be used as well for the simulation of the cell bead cultivation process. 


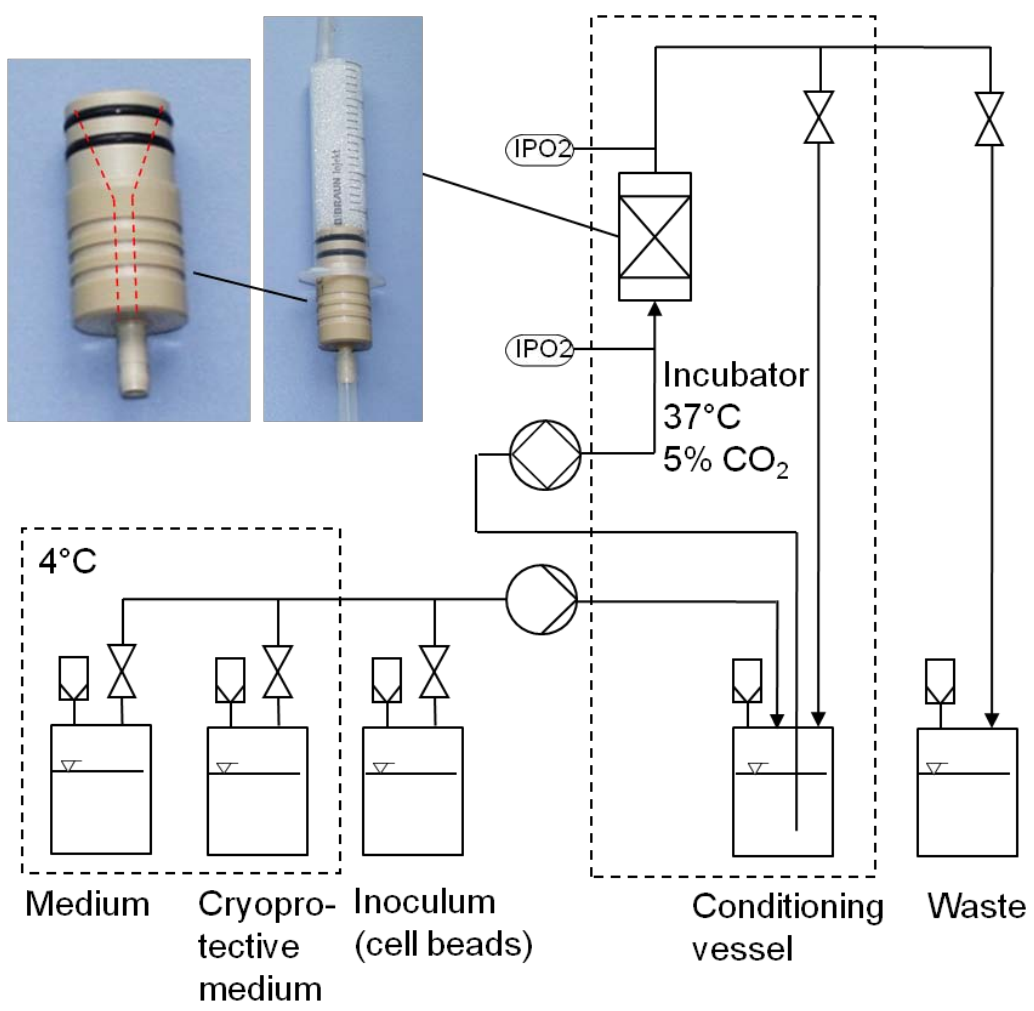

Figure 13: System for the cultivation of cell beads in syringe based fixed reactors.

\section{Cultivation of encapsulated cells}

Cultivations of cell beads were exemplarily performed under adipogenic conditions in a $1 \mathrm{~cm}^{3}$ scale (data not shown). Induction medium was applied for 3 days followed by 4 days cultivation with maintenance medium (Table 5). This cycle was repeated three times [14]. Medium, $50 \mathrm{ml}$ per cycle, was perfused at a superficial velocity of $1.28 \times 10^{-4} \mathrm{~m} / \mathrm{s}$ that is below the fluidization point. Reference cultures were performed in $25 \mathrm{~cm}^{2}$ T-flasks using the same protocol. 
Table 5: Composition of media for the adipogenic cultivation of cell beads [28].

\begin{tabular}{l|l}
\hline Induction medium & Maintenance medium \\
\hline DMEM + 10\% FCS & DMEM + 10\% FCS \\
$100 \mathrm{U} / \mathrm{ml}$ penicillin & $100 \mathrm{U} / \mathrm{ml}$ penicillin \\
$0.1 \mathrm{mg} / \mathrm{ml}$ streptomycin & $0.1 \mathrm{mg} / \mathrm{ml}$ streptomycin \\
$0.01 \mathrm{mg} / \mathrm{ml}$ insulin & $0.01 \mathrm{mg} / \mathrm{ml}$ insulin \\
$0.5 \mathrm{mM}$ 3-isobutyl-1-methyl-xanthin & - \\
$0.2 \mathrm{mM}$ indomethacin & - \\
$1 \mu \mathrm{M}$ dexamethason & - \\
\hline
\end{tabular}

Vitality was determined after 0, 100, 200, and 500 hours with the Trypan blue exclusion method after lysis of the cell beads using EDTA [28].

The vitality increased with advancing cultivation time, whereas the cell number decreased (Figure 14). This is explainable by a decomposition of apoptotic cells. Apoptosis may be triggered by the harvesting or the encapsulation process, or dominant in this case, by the cryopreservation of the cell beads prior to the cultivation. It could be shown that the vitality, and thus the quality of the beads is gradable during the cultivation process.
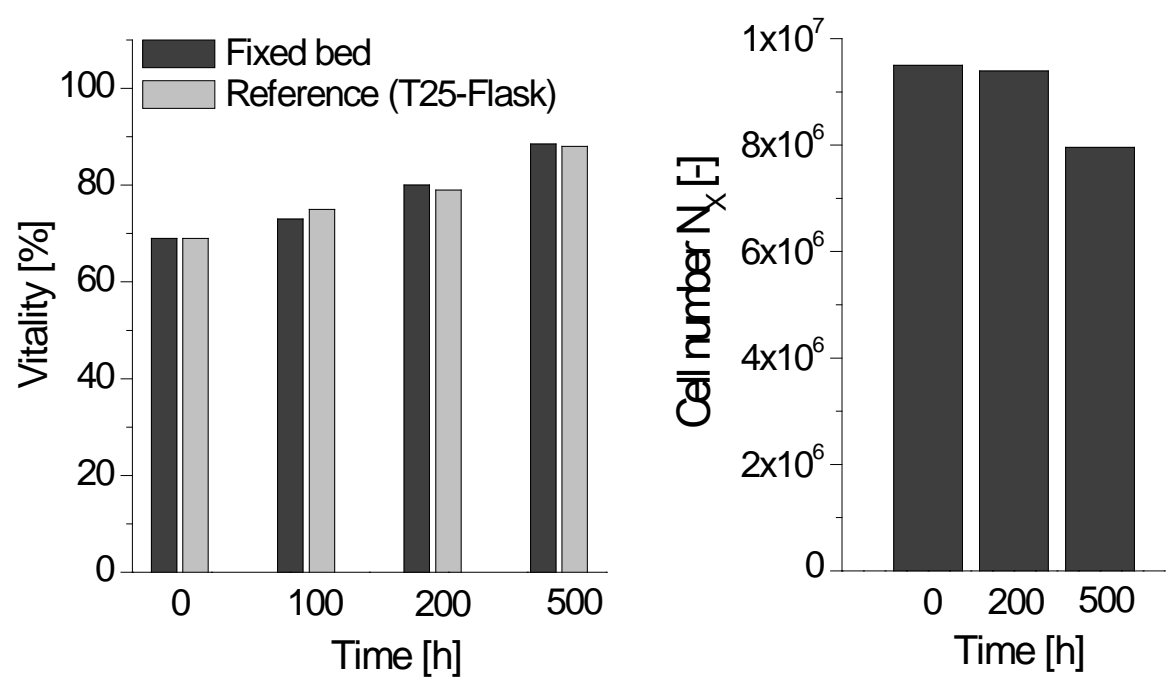

Figure 14: Time dependent vitality and cell number of cell beads cultured in fixed-bed reactors and in T-flasks (reference). 
As example an adipogenic differentiation protocol was applied, whereby the differentiation to adipocytes was verified by staining with the lipophilic fluorescence dye Nile red (Figure 15) [28]. Adipogenic cultured cell beads showed higher fluorescence intensity and thus are interpreted to be diffentiated to adipocytes. No differences between the fixed-bed culture and the reference culture in T-flasks are detectable.

Table 5 shows the kinetics obtained by fitting of the model parameter to the experimental data which were used for a theoretical scale up of the system.

Adipogenic

cultivation
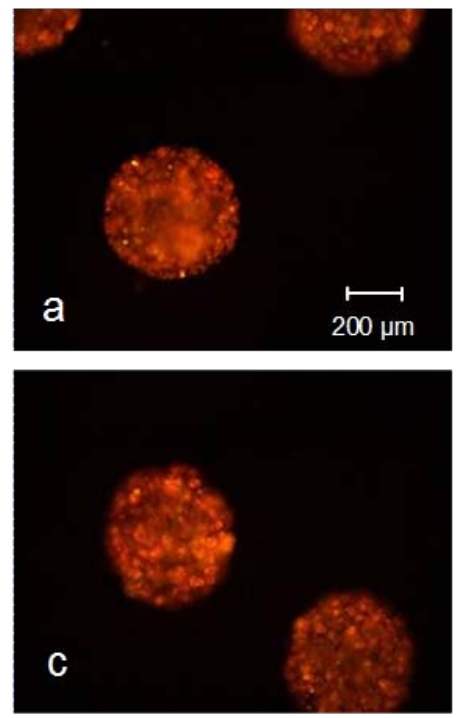

Non-adipogenic

cultivation
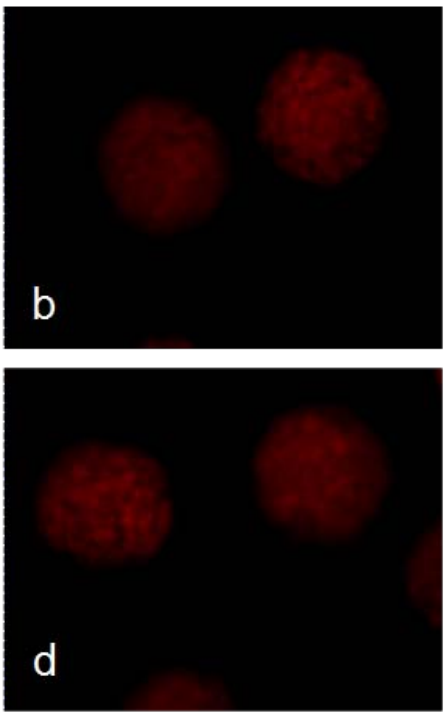

Figure 15: Nile red staining of cell beads which were cultured under adipogenic and non-adipogenic conditions in fixed-bed reactors or T25-flasks. 
Table 6: Consumption kinetics of encapsulated hMSC-TERT (cell beads) which were obtained by fitting of model parameters to the experimental data of the adipogenic cultivation in a $1 \mathrm{~cm}^{3}$ fixed-bed scale (Figure 14).

\begin{tabular}{lll}
\hline Growth rate $\mu_{\max }$ & 0 & {$[1 / \mathrm{d}]$} \\
Maximal glucose consumption rate $q_{G l c, \max }$ & $(7.3-9.4) \times 10^{-8}$ & {$[\mathrm{mg} / \mathrm{h} / \mathrm{cell}]$} \\
Monod constant $k_{M, q_{G l c}}$ & 0.06 & {$[\mathrm{mg} / \mathrm{ml}]$} \\
Oxygen consumption rate $q_{O x}$ & $5.5 \times 10^{-9}$ & {$[\mathrm{mg} / \mathrm{h} / \mathrm{cell}]$} \\
\hline
\end{tabular}

\section{Theoretical scale up of the cell bead cultivation process}

A calculational scale up was carried out for a cultivation of 200 single doses of cell beads of each $5 \mathrm{ml}$ (Figure 16). The inlet oxygen concentration was assumed to be air saturated. This can be realized, for example, by using membrane oxygenators.

For a calculation of the oxygen or glucose concentration profile in the cell bead, the following diffusion and diffusion-reaction equations were used:

$$
\begin{aligned}
& D_{C C} \cdot\left(\frac{d^{2} c_{C C}}{d r^{2}}+\frac{2}{r} \cdot \frac{d c_{C C}}{d r}\right)=q \cdot X_{C C} \\
& D_{A C} \cdot\left(\frac{d^{2} c_{A C}}{d r^{2}}+\frac{2}{r} \cdot \frac{d c_{A C}}{d r}\right)=0
\end{aligned}
$$

\section{Equation 11}

\section{Equation 12}

with the concentration in the cell containing core bead $c_{C C}$ as well as in the cell free alginate capsule $c_{A C}$, the effective diffusion coefficient in the core bead $D_{C C}$ and alginate capsule $D_{A C}$ and the cell density of the core bead $X_{C C}$.

It could be shown that an oxygen saturation in the medium of $40 \%$ leads to a oxygen saturation at the center of approximately $22 \%$ (Figure 16). The difference of glucose between the medium and the cell bead center is negligible. Thus, it can be assumed that no limitations of the cells at the center of a cell bead are expectable. 

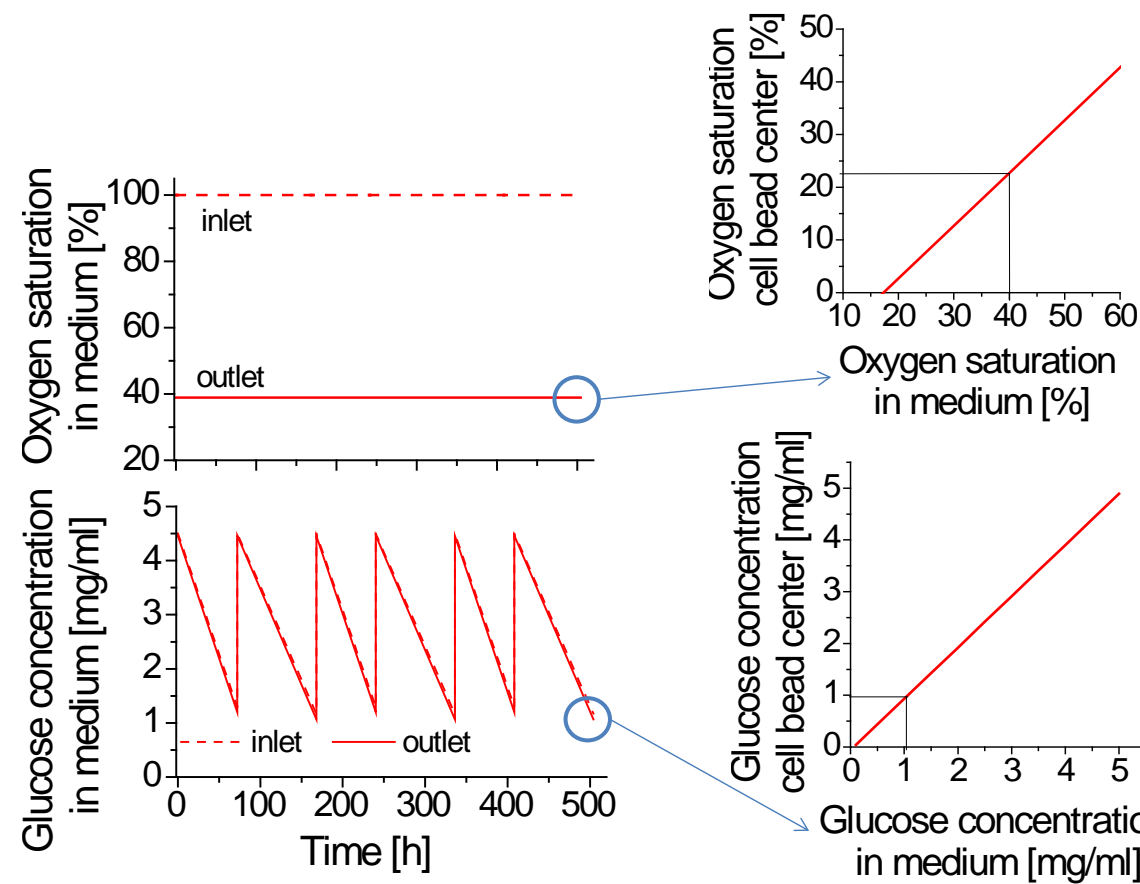

Oxygen saturation in medium [\%]

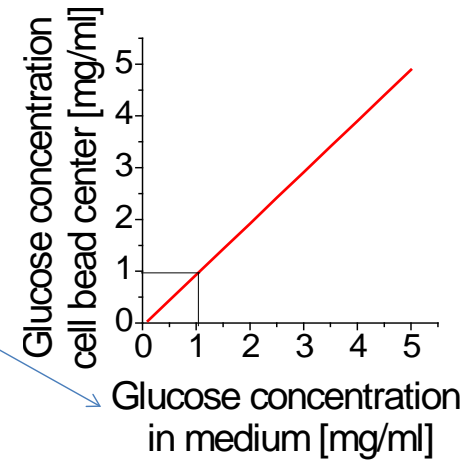

Figure 16: Simulated adipogenic cultivation of 200 single doses $\left(5 \mathrm{~cm}^{3}\right)$ of cell beads as well as the glucose and oxygen profile at the cell bead center. Medium volume per cycle: $40 \mathrm{~L}$, superficial velocity: $2.5 \times 10^{-4} \mathrm{~m} / \mathrm{s}$

\section{Conclusion and Outlook}

Two fixed-bed reactor systems for the production of stem cell based therapeutic implants were introduced. One system was developed for the expansion of the production cell line (hMSC-TERT) and a second for the cultivation of encapsulated cells in order to increase their vitality and thus the quality of the implants.

The fixed-bed system for the expansion of the production cell line is based on non-porous borosilicate glass spheres. Cells can be cultured and harvested with high yield and vitality. The separation of the cells from the carrier can be easily performed by flushing them out with the medium flow. This saves additional process steps.

The fixed-bed system for the cultivation of encapsulated cells is based on commercial available syringes in which the cell beads represent the bed. The advantage of this system is that it can be used as implantation tool after the cultiva- 
tion procedure. It could be shown that the vitality is gradable by the cultivation process. Furthermore, the application of an adipogenic differentiation protocol could be demonstrated.

Both systems can be automated and produced as disposable items due to their simple design.

The next steps will concern the development of a GMP-conform cryopreservation procedure for the cell beads and the implementation of the cultivation systems to the overall GMP-process of cell bead production.

\section{Acknowledgements}

The authors would like to thank the Federal ministry of Economics and Technology for financial support as well as the CellMed AG for providing the production cell line hMSC-TERT and the CellBeads ${ }^{\circledR}$.

\section{References}

1. Lanza, R.P., J.L. Hayes, and W.L. Chick, Encapsulated cell technology. Nature Biotech, 1996. 14: p. 1107 - 1111.

2. Freimark, D. and P. Czermak, Cell-based regeneration of intervertebral disc defects: review and concepts. Int J Artif Organs 2009. 32: p. 197203.

3. Baksh, D., L. Song, and R.S. Tuan, Adult mesenchymal stem cells: characterization, differentiation, and application in cell and gene therapy. $\mathrm{J}$ Cell Mol Med, 2004. 8: p. 301-316.

4. Chiu, R.C.J., Bone-marrow stem cells as a source for cell therapy. Heart Failure Rev., 2003. 8: p. 247-251.

5. $\quad$ Fraser, J.K., et al., Adult stem cell therapy for the heart. Int. J. Biochem. Cell Biol. , 2004. 36: p. 658-666.

6. Mimeault, M., R. Hauke, and S.K. Batra, Stem cells: A revolution in therapeutics-recent advances in stem cell biology and their therapeutic applications in regenerative medicine and cancer therapies. Clinical Pharmacology \& Therapeutics, 2007. 82: p. 252-264.

7. Simonsen, J.L., et al., Telomerase expression extends the proliferative life-span and maintains the osteogenic potential of human bone marrow stromal cells. Nat. Biotechnol., 2002. 20: p. 592-596.

8. Heile, A.M.B., et al., Cerebral Q1 transplantation of encapsulated mesenchymal stem cells improves cellular pathology after experimental traumatic brain injury. Neurosci. Lett. , 2009. 
9. Aris, R., The mathematical theory of diffusion and reaction inpermeable catalysts. Vol. 1. 1975, Oxford: Clarendon Press.

10. Bailey, J. and D.F. Ollis, Biochemical engineering fundamentals. 2. ed. 1986, New York: McGraw-Hill.

11. Froment, G.F. and K.B. Bischoff, Chemical Reactor Analysis and Design. 1979, New York: John Wiley.

12. Fassnacht, D., Fixed-bed reactors for the cultivation of animal cells. Fortschritt-Berichte VDI. Vol. 17. 2001, Düsseldorf: VDI-Verlag.

13. Willaert, R.G., G.V. Baron, and L. de Backer, Modelling of immobilised bioprocesses. Immobilised living cell systems, ed. R.G. Willaert, G.V. Baron, and L. de Backer. 1996, New York: John Wiley \& Sons.

14. Perry, R.H. and D.W. Green, Perry's Chemical Engineers' Handbook 2007: McGraw-Hill.

15. Weber, C., S. Gokorsch, and P. Czermak, Expansion and chondrogenic differentiation of human mesenchymal stem cells Int J Artif Organs, 2007. 30: p. 611-618.

16. Schop, D., et al., Growth, metabolism, and growth inhibitors of mesenchymal stem cells. Tissue Eng. A, 2009.

17. Higuera, G., et al. Qvantifying in vitro growth and metabolism kinetics of human mesenchymal stem cells using a mathematical model. , Qvantifying in vitro growth and metabolism kinetics of human mesenchymal stem cells using a mathematical model. Tissue Eng Part A, 2009. 15: p. 1-11.

18. Schop, D., et al., Expansion of mesenchymal stem cells using a microcarrier-based cultivation system: growth and metabolism. J. Tissue Eng. Regen. Med., 2008. 2: p. 126-135.

19. Lonergan, T., C. Brenner, and B. Bavister, Differentiation-related changes in mitochondrial properties as indicators of stem cell competence. J. Cell. Phys., 2006. 208: p. 149-153.

20. Conget, P. and J.J. Minguell, Phenotypical and functional properties of human bone marrow mesenchymal progenitor cells. J. Cell. Phys., 1999. 181: p. 67-73.

21. Guo, Z., et al., Biological features of mesenchymal stem cells from human bone marrow. Chin. Med. J., 2001. 114: p. 950-953.

22. Soukup, T., et al., Mesenchymal stem cells isolated from human bone marrow: cultivation, phenotypic analysis and changes in proliferation kinetics. Acta Med., 2006. 49: p. 27-33.

23. Peng, C.A. and B.A. Palson, Determination of specific oxygen uptake rates in human hematopoietic cultures and implications for bioreactor design. Ann. Biomed. Eng., 1996. 24: p. 373-381.

24. Pörtner, R., et al., Bioreactor design for tissue engineering. J. Biosci. Bioeng., 2005. 100: p. 235-245.

25. Acevedo, C.A., et al., A mathematical model for the design of fibrin microcapsules with skin cells. Bioprocess. Biosyst. Eng. , 2008. 
26. De Leon, A., H. Mayani, and O.T. Ramırez, Design, characterization and application of a minibioreactor for the culture of human hematopoietic cells under controlled conditions. Cytotechnol., 1998. 28: p. 127-138.

27. Youn, B.S., A. Sen, and L.A. Behie, Scale-up of breast cancer stem cell aggregate cultures to suspension bioreactors. Biotechnol. Prog., 2006. 22: p. 801-810.

28. Weber, C., et al., Cultivation and differentiation of encapsulated hMSCTERT in a disposable small-scale syringe-like fixed bed reactor. Open Biomed. Eng. J. , 2007. 1: p. 64-70. 